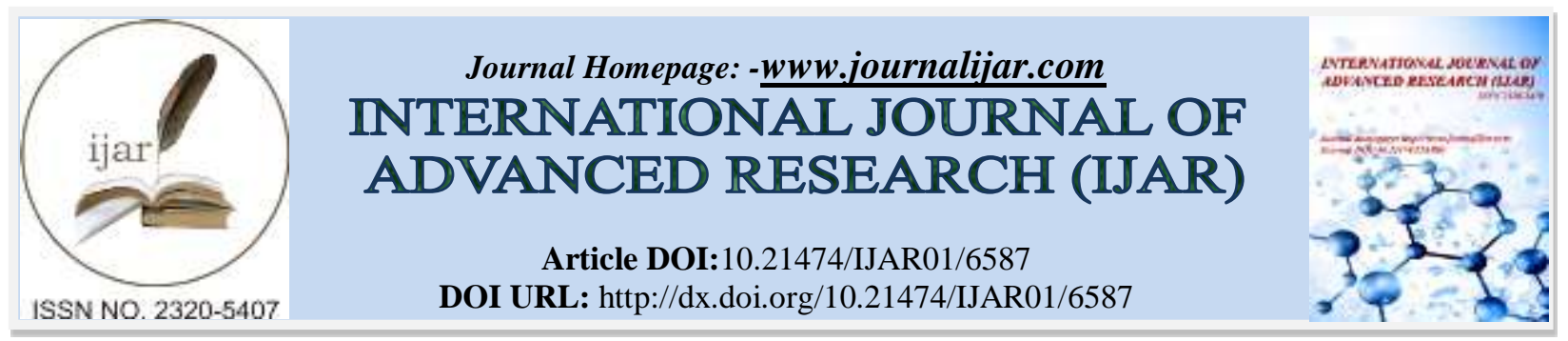

RESEARCH ARTICLE

\title{
ACCEPTANCE OF COSMETIC SURGERY AMONG FEMALES IN PRINCESS NORA BENT ABDULRAHMAN UNIVERSITY.
}

\begin{abstract}
Khairiah A. Alsumali, Rawan A. Al shammari, Sahar M. Al shammery, Wafa Al saab, Bashayer Al Zayed, Nourah Al-Rashed, Norah Al shehry and Suhad Al Nasser.
\end{abstract}

\section{Manuscript Info}

Manuscript History

Received: 19 December 2017

Final Accepted: 21 January 2018

Published: February 2018

Keywords:-

Sponge, Levantine, Mediterranean, Antibacterial Agent, Pathogenic Bacteria.

\section{Abstract}

Five marine sponges were collected from six stations from the Levantine Basin in the vicinity of Alexandria city, Egypt (Spongia sp., Cinachyrella sp., Ciocalypta penicillus, Axinella verrucosa, and Plakortis simplex).The antibacterial activities against seven pathogenic bacteria; Aeromonas hydrophila, Staphylococcus aureus ATCC6538, Pseudomonas aeruginosa ATCC8739, Vibrio damsela, Bacillus cereus, Streptococcus faecalis and Escherichia coli, were done. The results showed that the acetone extract of Spongia sp. had a broad spectrum and was the most effective against $A$. hydrophila $(\mathrm{AU}=32.1)$. It was followed by ethanol extract (AU=25.5). Ciocalypta penicillus and A. verrucosa showed higher antibacterial activity against E. coli, where AUs were 17.4, 17.4 and 16.0 for ethanol, acetone, and methanol extracts, respectively. All extracts treated by trypsin and boiling, completely lost their bioactivities except in some cases, the bioactivities decreased to low levels. The ethanol extract of $C$. penicillus lost about $64.4 \%$ of AU against $E$. coli. Also, the methanol extract of A. verrucosa lost about $56.4 \%$ of AU against E. coli. The GC-MS patterns confirmed that several substances could be easily affected by proteases and temperature, such as fatty acids and their derivatives. Steroids (digoxigenin) and terpenoids ( $\beta$-Carotene betulin, astaxanthin, and rhodopsin) were also estimated to be among these extracts.

Copy Right, IJAR, 2018,. All rights reserved.

\section{Introduction:-}

After being almost restricted to celebrities and the wealthy members of society decades ago, cosmetics nowadays have reached their peak and became a very popular trend among all classes and age groups, especially the youth. Saudi Arabia was ranked 23rd with a total number of 96,667 surgical and non-surgical procedures, among 25 countries with the highest rates of Cosmetic procedures worldwide. The present study purpose was to ascertain the factors that influence or motivate patients to accept cosmetic surgery.

\section{Objectives:-}

This study was conducted to identify the factors influencing acceptance of cosmetic procedures rather than studying the acceptance rates only with respect to " socio-demographic state, self esteem and religious considerations" among students in Princess Norah University, Riyadh. 


\section{Methodology:-}

Cross-sectional study of a convenient sample encompassed 500 students in all colleges at Princess Nourah Bent Abdul-Rahman University (82.6\% from non-health collages and $17.4 \%$ from health collages ). It was conducted between 1st of September 2014 and 5th of June 2015. Self-administrated questionnaire was distributed to all participants. Data collected included; socio-demographic data, validated cosmetic surgery acceptance scale, Selfesteem assessment scale and religious beliefs of plastic surgeries.

\section{Result:-}

The mean age of the overall participants was $20.9 \pm 1.9$ years. Students who were divorced/widow significantly scored higher acceptance scores when compared to other students ( 44.7 versus $24.0, \mathrm{p}=0.04$ ). Students who reported having minor or major cosmetic procedures, themselves or their relatives, had shown higher acceptance scores when compared to those who did not have similar history. In contrast to that, students who believed that cosmetic surgeries are prohibited by Islam, scored lower acceptance score $(23.6 \pm 13.8)$ when compared to those who disagreed (27.8 \pm 15.2$)$. Negative correlation was confirmed between self-esteem and acceptance of cosmetic procedures.

\section{Conclusion:-}

These finding clearly suggests that the level of acceptance of plastic surgeries among female university students is vastly affected by their marital status and their perceived self-esteem. Relatives and friends own experience of plastic procedures intensively encourage the female students to decide for themselves. Religious beliefs are crucial in taking the decision to undergo plastic surgery. 